\title{
RpoE fine tunes expression of a subset of SsrB-regulated virulence factors in Salmonella enterica serovar Typhimurium Suzanne E Osborne ${ }^{1}$ and Brian K Coombes*1,2
}

\author{
Address: ${ }^{1}$ Michael G. DeGroote Institute for Infectious Disease Research, Department of Biochemistry and Biomedical Sciences, McMaster \\ University, Hamilton, ON, Canada and ${ }^{2}$ Laboratory for Foodborne Zoonoses, Public Health Agency of Canada, Guelph, ON, Canada \\ Email: Suzanne E Osborne - osborns@mcmaster.ca; Brian K Coombes* - coombes@mcmaster.ca \\ * Corresponding author
}

Published: 26 February 2009

BMC Microbiology 2009, 9:45 doi:10.1 |86/147|-2/80-9-45

Received: 15 October 2008

Accepted: 26 February 2009

This article is available from: http://www.biomedcentral.com/I47I-2/80/9/45

(C) 2009 Osborne and Coombes; licensee BioMed Central Ltd.

This is an Open Access article distributed under the terms of the Creative Commons Attribution License (http://creativecommons.org/licenses/by/2.0), which permits unrestricted use, distribution, and reproduction in any medium, provided the original work is properly cited.

\begin{abstract}
Background: The survival of Salmonella enterica within the intracellular host niche requires highly co-ordinated expression of virulence effectors predominantly regulated by the SsrAB twocomponent regulatory system. S. enterica serovar Typhimurium mutants lacking the ssrAB genes are avirulent in mice, highlighting the importance of this regulatory system in vivo. Mutants lacking the gene encoding the alternative sigma factor $\sigma^{\mathrm{E}}(\mathrm{rpoE})$ are also highly attenuated for intracellular survival, pointing to a potential connection with the SsrAB regulatory system.

Results: In this study we demonstrate that RpoE is involved in fine-tuning the expression of a subset of SsrB-regulated genes found in the Salmonella pathogenicity island-2 (SPI-2) genetic locus that encodes a horizontally acquired type III secretion system, and unlinked genes integrated into this regulon that are required for virulence in host animals.

Conclusion: These data point to a potential connection between the virulence phenotype of strains lacking ssrB and $r p o E$, and highlight new transcriptional regulation that might be essential for appropriate temporal and spatial control of the virulence-associated type III secretion system during host infection.
\end{abstract}

\section{Background}

Salmonella enterica are enteric pathogens that acquired a type III secretion system (T3SS) through horizontal gene transfer of a genomic island termed Salmonella Pathogenicity Island 2 (SPI-2) [1,2]. The SPI-2-encoded T3SS and its translocated effectors modify the intracellular host niche for Salmonella replication [3-5]. SPI-2 also has genes, ssrA and $s s r B$, which code for SsrAB, a two-component regulatory system needed for expression of the T3SS $[6,7]$. SsrB regulates the expression of SPI-2 encoded substrate effectors including $s s a B$, as well as several integrated virulence effectors such as sseL [8] and $\operatorname{srfN}[9]$ that are encoded elsewhere on the chromosome but that have integrated into the SsrB regulon. Mutants lacking $s s r A B$ are unable to survive within macrophages and are avirulent in mice [1].

Alternative sigma factors coordinate gene expression in response to environmental cues sensed by the bacterium. Sigma factors have a specific recognition motif at the - 35 and -10 positions and function to concentrate RNA polymerase at a subset of promoters [10]. One alternative sigma factor, $\operatorname{RpoE}\left(\sigma^{\mathrm{E}}\right)$ responds to envelope stress at the cell surface. Release of $\sigma^{\mathrm{E}}$ from its inner membrane anchored anti-sigma factor, RseA, leads to induction of genes required to maintain cell envelope integrity [11]. 
SsrB-regulated translocated effectors protect $S$. Typhimurium against host cell defences such as oxidative stress and antimicrobial peptides that perturb bacterial membrane integrity and provide a stimulus for $\sigma^{\mathrm{E}}$ release $[4,12-15]$. Although proficient at cellular invasion, $r p o E$ or $s s r B$ mutants are highly attenuated for intracellular survival in both cultured cells and animal hosts [16]. In addition, the expression of $r p o E$ and $s s r B$ is up-regulated within macrophages [17]. Links between RpoE and virulence gene expression is evident in other bacterial systems as well. Deletion of rseA in Yersinia pseudotuberculosis causes elevated virulence effector synthesis and secretion [18], establishing links between alternative sigma factors and virulence-specific regulators. Taken together, a connection between $\sigma^{\mathrm{E}}$ and SsrB is suggested from the available literature, however the role of $\sigma^{\mathrm{E}}$ in activating SsrB-regulated genes has not been studied.

We tested the hypothesis that RpoE is involved in expression of genes that use the SsrB response regulator for activation. By testing six promoters representing four classes of SsrB-regulated promoters ((i) two type III secretion structural operons in SPI-2, (ii) the effector operon in SPI2, (iii) two effector genes unlinked with SPI-2, and (iv) an integrated virulence gene unlinked with SPI-2) we demonstrate that RpoE elicits an effect on a subset of SsrB-regulated genes. This effect was bidirectional depending on the promoter and was downstream of $s s r B$ expression itself, since deletion of $r p o E$ had no effect on SsrB levels in the mutant cells. These data help unite the virulence phenotypes of strains lacking SsrB and RpoE, and highlight new transcriptional regulation that might be essential for appropriate temporal and spatial control of the virulenceassociated type III secretion system during host infection.

\section{Results}

Deletion of rpoE affects a subset of SsrB-regulated virulence genes

Salmonella virulence gene expression is coordinated in vivo and may be regulated, in part, by alternative sigma factor(s) in order to quickly respond to the host environment. To date, no sigma factor has been identified as regulating SsrB-dependent virulence genes. To start, we first screened four alternative sigma factor mutants of $S$. Typhimurium ( $r p o S, r p o N, r p o E, r p o H)$ for their ability to express a key virulence gene, $s s e B$, that requires SsrB for expression and whose gene product is essential for intracellular pathogenesis. For an $r p o H$ deletion, this strain was only viable at temperatures below $30^{\circ} \mathrm{C}$. Since SPI-2 gene activation is integrated into a thermosensing circuit [19] we were unable to test the role of $\sigma^{\mathrm{H}}$ in this study (data not shown). In this screen, $r p o S$ deletion resulted in a slight increase in SseB levels (Figure 1A) indicating a role for RpoS in the repression of SPI-2. Both $r p o E$ and $r p o N$ deletions resulted in decreased SseB levels with a more pro- nounced effect in the rpoE deletion. Since we were predominantly interested in sigma factors that activate SPI-2 and which could be linked to the previous observation that $r p o E$ mutants are highly attenuated in vivo we choose to focus on RpoE in the current study, which had the most influence on SseB levels in the cell.

An unmarked in-frame deletion of $r p o E$ was then generated in S. Typhimurium strain SL1344 and we verified that this in-frame deletion had the same effect on SseB as
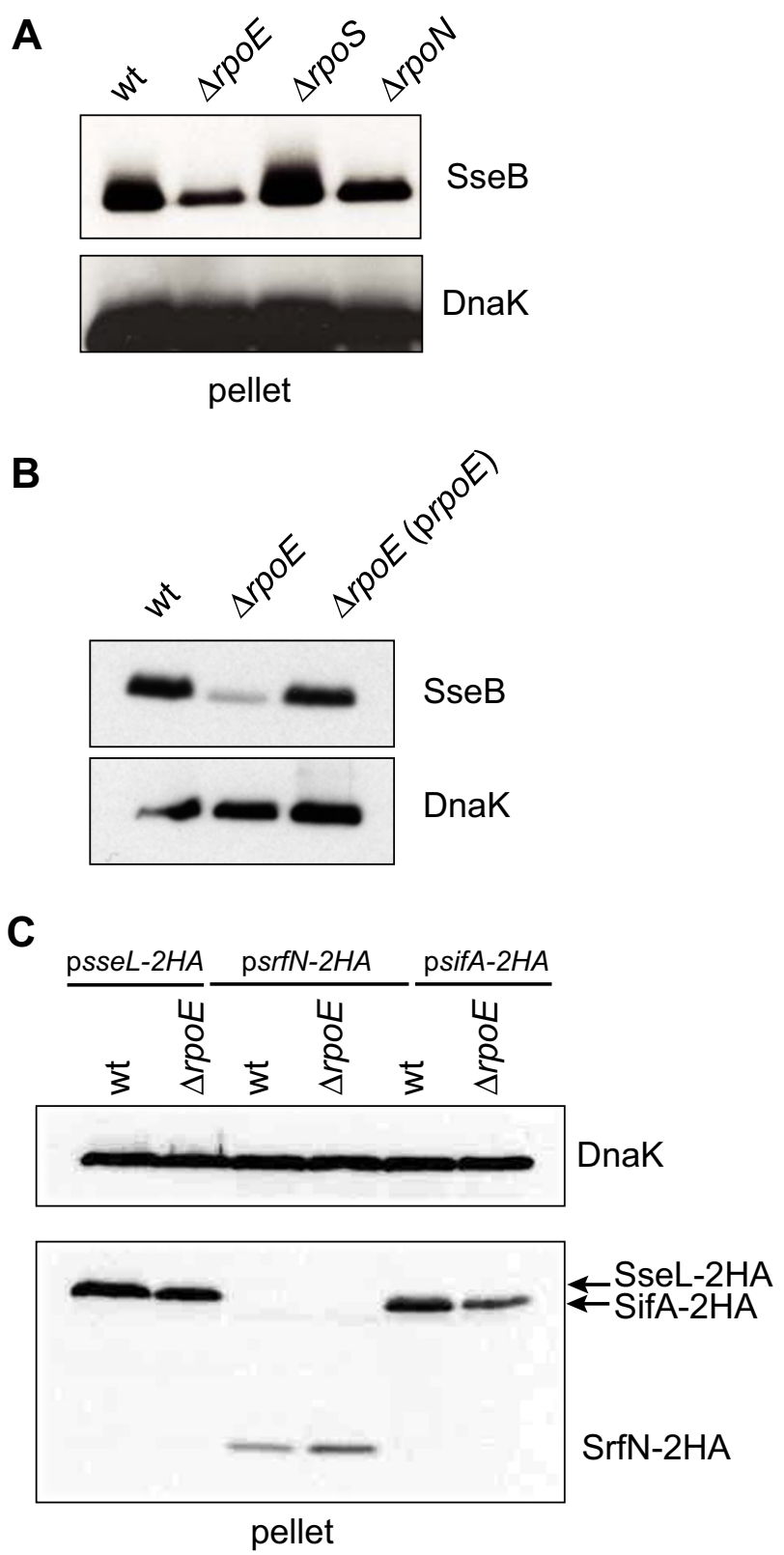

Figure I 


\begin{abstract}
Figure I
Loss of rpoE changes the abundance of virulence factors in Salmonella. (A) wild type (wt), $\Delta r p o E, \Delta r p o S$, and $\Delta$ rpoN S. Typhimurium 14028s were grown for 6 hours under SsrB-inducing conditions. Lysates were probed by western blot for SseB, a component of the T3SS needle complex. (B) Western blot was performed as above and lysates probed for SseB in wild type (wt) S. Typhimurium SLI344, $\triangle r p o E$ and in $\triangle r p o E$ complemented with pWSK29 carrying full length $r p o E$ with endogenous promoters. (C) Wild type $S$. Typhimurium SLI 344 and $\triangle$ rpoE cells were immunoblotted as above and lysates probed for SseL-2HA, SrfN-2HA and SifA-2HA which were expressed from their endogenous promoters in PWSK29. Blots were probed for DnaK as a control. The experiment was performed three times with similar results.
\end{abstract}

the rpoE::cat mutant used previously (Figure 1B). A lowcopy plasmid containing full-length $r p o E$ and the three endogenous promoters that can drive its expression [20] was able to restore wild type levels of SseB to $\Delta r p o E$ cells (Figure 1B) demonstrating that the results were specific to the rpoE deletion. In these complementation experiments, attempts were made to examine the levels of SseB secreted into the culture supernatant [21], however consistent with previous observations $[22,23]$ perturbations to the $r p o E$ pathway increased cell lysis resulting in contamination of secreted fractions with cytosolic proteins which precluded accurate interpretation (data not shown).

In order to examine the effect of $\sigma^{\mathrm{E}}(r p o E)$ on the expression of a broad range of SsrB-regulated virulence genes, we tested whether or not the effect of $r p o E$ deletion was specific to $s s e B$ or if it extended to other SsrB-regulated genes. To do this we examined the levels of SseL-2HA, SifA-2HA and SrfN-2HA expressed from their endogenous promoters under SPI-2 inducing conditions (Figure 1C). Consistent with the results for SseB, there was a decrease in SifA$2 \mathrm{HA}$ levels in $\triangle r p o E$ compared to wild type, although deletion of rpoE did not have an effect on SseL-2HA. Relative to its expression in wild type cells, the level of SrfN-2HA was reproducibly increased in the $\Delta r p o E$ cells, suggesting a role for $\sigma^{\mathrm{E}}$ in the repression of $\mathrm{SrfN}$, although it is unlikely that this is through a direct mechanism.

\section{RpoE is involved in transcriptional activity of a subset of virulence genes}

In order to confirm the effect of $\sigma^{\mathrm{E}}$ on the expression of a broad range of SsrB-regulated virulence genes, we used wild type and $\triangle r p o E$ cells and integrated into the chromosome individually six single-copy transcriptional fusions representing promoters for four classes of SsrB-dependent genes or operons ((i) type III secretion effector operon
(sseA); (ii) structural operon I (ssaB); (iii) structural operon II (ssaG); (iv and v) effectors encoded outside of SPI-2 (sseL and sifA); and (vi) integrated virulence genes unlinked to SPI-2 $(s r f N)$ [9]. Transcriptional fusions to lacZ of the sse A, ssaB, ssaG, sseL, sifA and srf $N$ promoters (mapped previously; $[9,24]$ were integrated into the chromosome of wild type and $\triangle r p o E$ cells and then grown in the SsrB-activating medium LPM. The activity of each promoter was measured using a $\beta$-galactosidase assay during exponential growth. Although $\Delta r p o E$ was observed to have a slightly prolonged lag phase relative to wild type cells under these experimental conditions, at later time points the mutant grew similarly to wild type. To account for any differences in growth kinetics of the cultures, all data was normalized to the optical density at $600 \mathrm{~nm}$ of the culture, which permitted direct comparisons.

In wild type cells, promoter activity from all the transcriptional fusions was high, as expected, because LPM medium is highly inducing for SsrB activity [21]. In contrast, promoter activity for $s s e A, s s a B$, and sifA decreased in the $r p o E$ mutant compared to wild type cells (Figure 2A, B and 2D), whereas promoter activity from the ssaG and $s r f N$ reporters was upregulated in the $r p o E$ mutant (Figure $2 \mathrm{C}$ and $2 \mathrm{~F}$ ). $\beta$-galactosidase activity observed from the sse $L$ reporter was unaltered in the rpoE deletion compared to that in wild type cells (Figure 2E). These data are consistent with the protein levels detected for these gene products. Together, these data indicate that $\sigma^{\mathrm{E}}$ can have a variable and bidirectional effect on SsrB-regulated virulence genes.

\section{The effect of RpoE on virulence genes is downstream of ssrB expression}

The variable effects of $r p o E$ deletion on SsrB-regulated effectors suggested that RpoE might direct transcription downstream of $s s r B$ expression. To test this, we replaced the $s s r B$ gene in $\triangle r p o E$ and wild type cells with an ssrB::FLAG allele [19] and examined the levels of SsrB protein in the strains by western blot. There was no change in the levels of SsrB-FLAG between wild type and $\triangle r p o E$ cells (Figure 3), indicating that the effects of RpoE on the four classes of virulence gene promoters examined here was not mediated through changes to SsrB protein levels. Together these data establish a role for RpoE in the finetuning of virulence gene expression in $S$. Typhimurium.

\section{Discussion}

In this work we found that the alternative sigma factor, $\sigma^{\mathrm{E}}$, is involved in fine tuning the expressing of a subset of SsrB-regulated virulence genes required for Salmonella pathogenesis. Although the effect of $r p o E$ deletion on promoter activity in some cases was mild, we have previously shown that gene regulators providing only modest transcriptional input have a profound influence on bacterial 

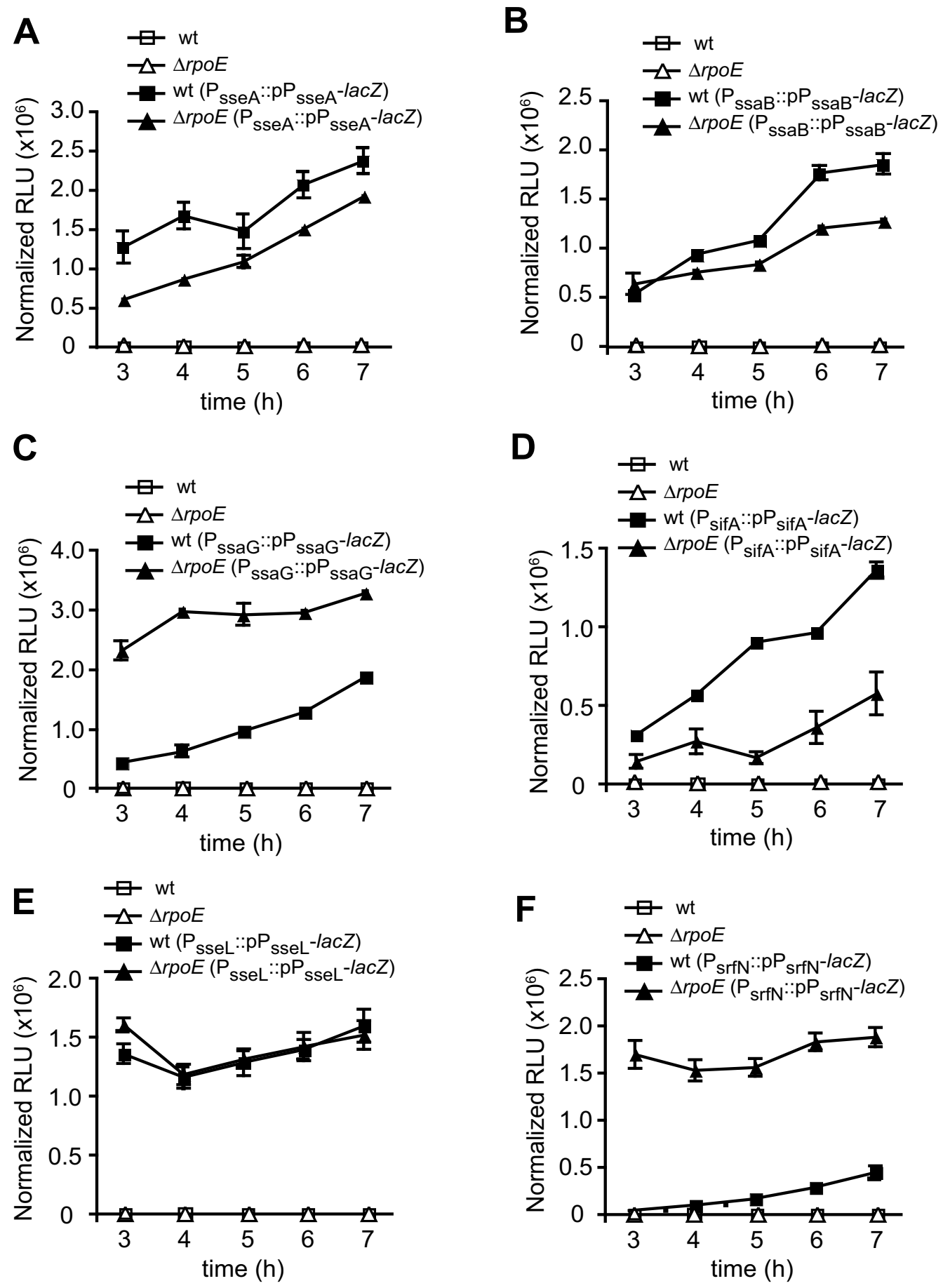

Figure 2

The transcriptional activity of SsrB-regulated virulence genes is affected by an rpoE deletion. Wild type and $\Delta r p o E$ cells carrying single-copy chromosomal transcriptional reporters of $(A) P_{\text {sseA }}:: P_{\text {sse }}-l a c Z$, (B) $P_{\text {ssaB }}:: P_{\text {ssaB }}-l a c Z,(C) P_{\text {ssaG }}:: p P_{\text {ssaG }}{ }^{-}$

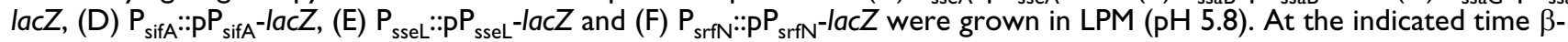
galactosidase activity was measured and expressed as relative light units (RLU) normalized to optical density of the culture. Wild type and $\Delta r p o E$ cells lacking the transcriptional reporters were used as controls in each experiment. Data are the means with standard error from triplicate determinations from three independent experiments. 
ssrB::FLAG

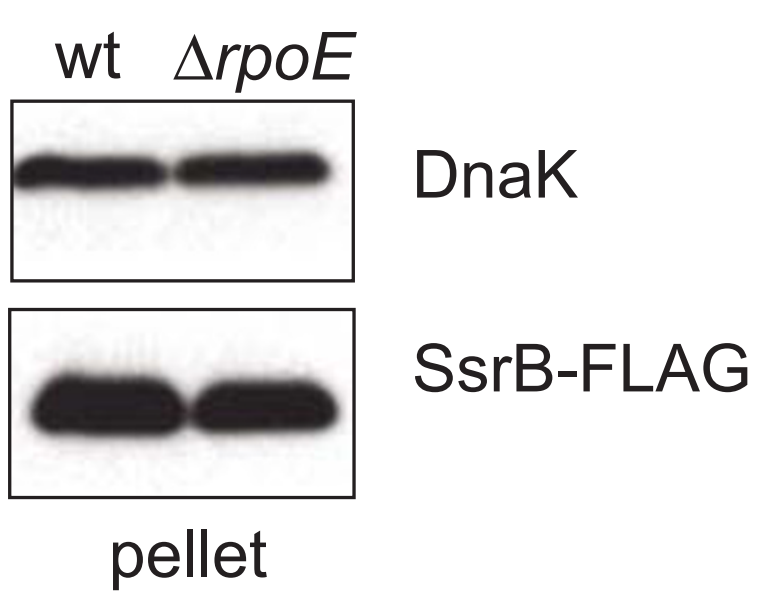

Figure 3

The effect of RpoE on SsrB-regulated genes is downstream of ssrAB expression. The ssrB gene in wild type and $\triangle r p o E$ cells was replaced with an ssrB-FLAG allele in its native location on the chromosome. Cells were grown under SsrB-activating conditions for six hours and lysates were probed by western blot to detect SsrB-FLAG and intracellular DnaK as a control. The data shown are representative of two experiments performed independently with identical results.

fitness in a host animal [25]. In cases where the regulator is deleted, the loss of genetic fine-tuning causes incongruous changes in the timing and magnitude of virulence gene expression, leading to fitness loss and strong attenuation. We predict that RpoE confers a similar fine-tuning effect on Salmonella virulence gene expression that is required for optimal within-host fitness during infection.

When we examined the -10 and -35 positions of the promoters studied here relative to the transcriptional start sites identified previously [24], these promoters did not appear to contain $\sigma^{\mathrm{E}}$ consensus sequences. Instead they appeared to have consensus sites for $\sigma^{70}$. Although a bioinformatics screen identified $\sigma^{\mathrm{E}}$ consensus sequences upstream of the SPI-2 genes ssaU, ssaJ, sscA and ssaC [26], these genes were not tested for $\sigma^{\mathrm{E}}$-dependence in the present study because the identified consensus sites are in coding sequence within operons, and as a result may not be directly relevant. Due to the high degree of conservation in $\sigma$ factor binding sequences, $\sigma^{\mathrm{E}}$ may not be directly regulating SsrB-dependent promoters. The lack of a canonical $\sigma^{\mathrm{E}}$ sequence at these promoters suggests that another regulatory gene may be epistatic to $\sigma^{\mathrm{E}}$ or that these promoters encode functional, but non-canonical $\sigma^{\mathrm{E}}$ binding sites due to their horizontal acquisition and gradual integration into the $\sigma^{\mathrm{E}}$ regulatory network. This integration may help Salmonella coordinate expression of the virulence-associated T3SS in response to host factors that compromise bacterial membrane integrity (Figure 4). This mechanism would activate a restorative $\sigma^{\mathrm{E}}$ pathway, which is consistent with the enhanced susceptibility of $r p o E$ mutants to oxidative stress and antimicrobial peptides $[13,15,16]$, both of which perturb membrane integrity in vivo. Although there is no evidence that $\sigma^{\mathrm{E}}$ can directly repress transcription, the negative effect on two promoters observed here might be due to an intermediate RpoE-regulated repressor or compensatory effect where loss of $r p o E$ increases the relative abundance of another sigma factor that can directly activate the $s s a G$ and $s r f N$ promoters. Future work will be required to resolve these possibilities.

Our results indicate that $r p o E$ deletion has no effect on SsrB levels under SPI-2 inducing conditions suggesting that the $\sigma^{\mathrm{E}}$ pathway regulates effector expression downstream of $s s r A B$ transcription. Unlinking $s s r A B$ transcription from the $\sigma^{\mathrm{E}}$ regulon would be advantageous to the cell to prevent commitment to a virulence gene expression program in response to envelope stress not associated with infection. The results from this study demonstrate that $\sigma^{\mathrm{E}}$ has the ability to affect expression of SsrB-regulated virulence genes and offers potential insight into the virulence attenuation of $r p o E$ mutants. Although when considered individually, each promoter was modestly affected by deletion of $r p o E$, the cumulative effects of mild rewired inputs on multiple virulence promoters has been shown to severely compromise in-host fitness and virulence ability [25].

\section{Conclusion}

Based on these and other data [4,12-15], the genetic interaction between $\sigma^{\mathrm{E}}$ and a subset of SsrB-regulated genes may serve to coordinate the spatial and temporal activation of virulence genes in a host setting, likely in response to membrane damage resulting from oxidative antimicrobial systems and membrane-targeted host defence peptides.

\section{Methods}

\section{Strains and Growth Conditions}

Bacteria were propagated at $37^{\circ} \mathrm{C}$ with aeration in LuriaBertani (LB) broth. S. enterica serovar Typhimurium ( $S$. Typhimurium) strain 14028 s with inactivating mutations in $r p o E, r p o S, r p o N$ and $r p o H$ were provided by Ferric Fang (University of Washington, Seattle, WA) [27]. $\Delta r p o H$ was grown at $30^{\circ} \mathrm{C}$ and $\Delta r p o N$ was supplemented with $2 \mathrm{mM}$ L-glutamine. An unmarked, in-frame deletion of $r p o E$ was 


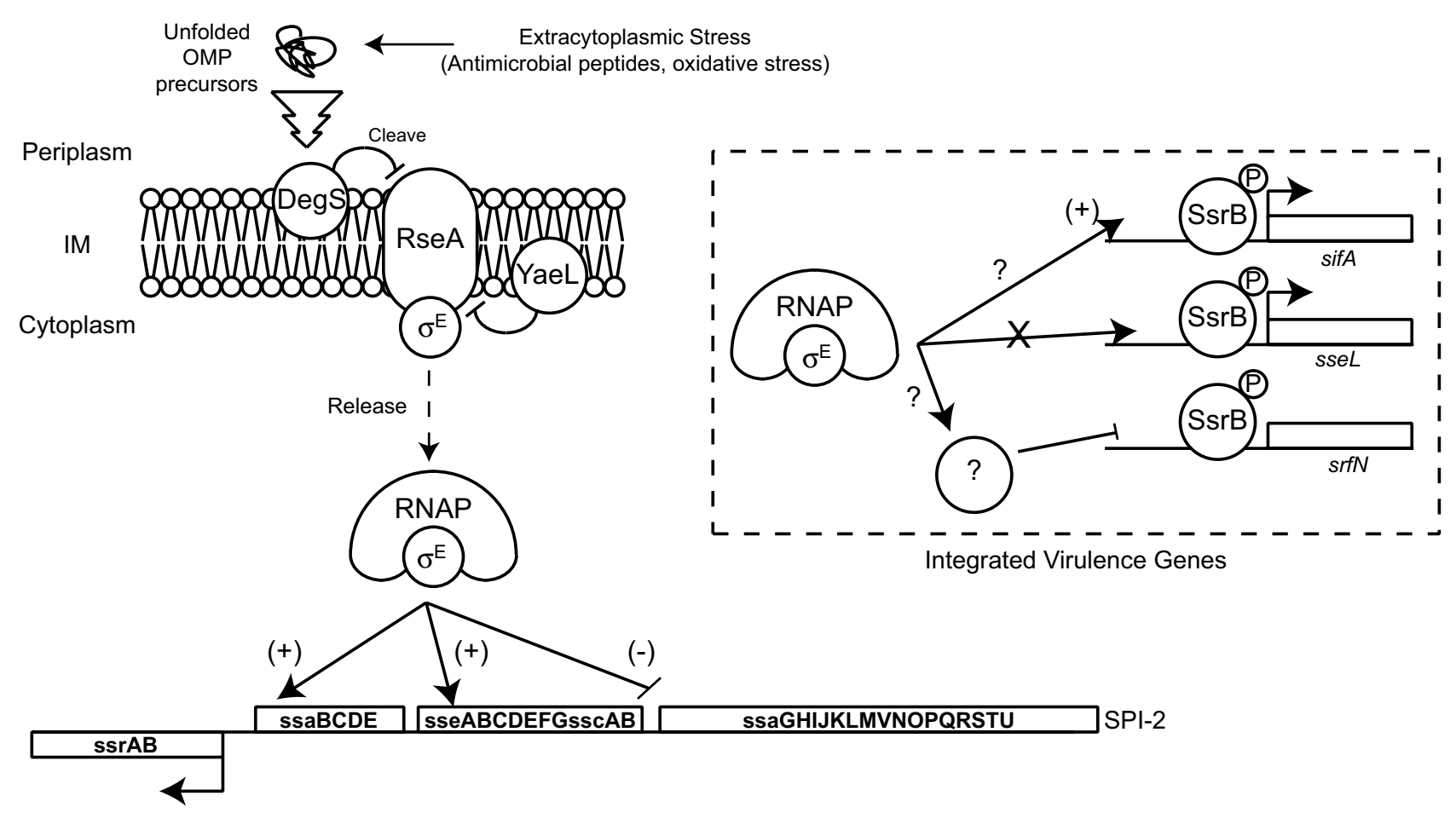

\section{Figure 4}

Model for $\sigma^{\mathrm{E}}$-dependent regulation of the SsrB regulon. Membrane-targeting host defences including reactive oxygen stress and antimicrobial peptides cause an accumulation of unfolded outer membrane proteins (OMPs) and stimulate the cleavage of the anti-sigma factor RseA consequently releasing $\sigma^{\mathrm{E}}$ into the cytoplasm where it directs RNA polymerase to a subset of SPI-2 promoters. RpoE can positively or negatively regulate SsrB-regulated genes including integrated virulence genes unlinked with SPI-2 but has no effect on some effector genes such as sseL. This regulatory pathway may have evolved to coordinate virulence gene expression with host infection by responding to host-specific defence pathways that perturb the bacterial outer membrane.

made in $S$. Typhimurium strain SL1344 by $\lambda$ Red recombination [28] using primers BKC187 and BKC188. Mutants were screened for loss of $r p o E$ using primers BKC193 and BKC194. To generate an ssrB::FLAG allele in $\triangle r p o E$, the ssrB::FLAG allele from wild type SL1344 [19] was transduced into $\Delta r p o E$ by P22-mediated transduction. All plasmids and strains used in this work are described in Table 1. Primer sequences for mutant and plasmid construction are listed in Table 2.

\section{Plasmid Construction}

A complementation construct for $r p o E$ was generated that included the three endogenous promoters (rpoEp1, rpoEp2, rpoEp3) identified in Salmonella [20] plus the wild type rpoE gene. This construct was cloned into the low-copy plasmid pWSK29 using primers SEO095 and SEO096 as a SalI and $\mathrm{XbaI}$ fragment. Constructs were verified by sequencing and transformed into $S$. Typhimurium SL1344 $\triangle r p o E$ and selected on LB agar with appropriate antibiotics. The promoters for ssaB (SEO005 and SEO006), ssaG (SEO011 and SEO012), sifA (SEO205 and SEO206), sseL (BKC185 and BKC186) and srfN (BKC183 and BKC184) were cloned into pIVET5n [29] to generate single-copy transcriptional fusions to lacZ. Reporters were transformed into E. coli SM10 $\lambda$ pir, conjugated into SL1344 and merodiploid cells were selected on LB agar with appropriate antibiotics. Transcriptional fusions, including a previously constructed reporter for the sseA promoter [30], were integrated into the chromosome of wild type and $\triangle r p o E$ cells using homologous recombination. The promoters we chose use the SsrB response regulator for expression of the downstream gene or operon, and include both SPI-2-encoded and non-SPI2-encoded virulence effectors representing structural apparatus genes and effector substrates of the type III secretion system [8,30-35]

\section{Chemiluminescent $\beta$-galactosidase Assay}

Reporter strains were inoculated from an overnight culture into culture medium (LPM pH 5.8) that induces SsrB- 
Table I: Strains and plasmids used in this study

\begin{tabular}{|c|c|c|}
\hline Strain or plasmid & Genotype or description a & Reference \\
\hline \multicolumn{3}{|l|}{ Plasmids } \\
\hline pKD46 & repAI0I ts, oriRI0I, araC-P ${ }_{\text {araB }}$-gam-bet-exo, bla & {$[28]$} \\
\hline PCP20 & $\mathrm{FLP}^{+}, \lambda \mathrm{cl}^{8} 57^{+} \lambda \mathrm{P}_{\mathrm{R}} \mathrm{Rep}^{\mathrm{ts}}, \mathrm{Amp}^{\mathrm{R}}, \mathrm{Cm}^{\mathrm{R}}$ & {$[28]$} \\
\hline pKD3 & pANTSy derivative, $F R T$-flanked cat from $\mathrm{pSCl} 40, \mathrm{Cm}^{\mathrm{R}}$ & [28] \\
\hline prpoE & $r p o E$ with endogenous promoters in pWSK29, Amp $\mathrm{R}^{\mathrm{R}}$ & This work \\
\hline psrfN-2HA & srfN with endogenous promoter and C-term. tandem HA fusion in pWSK I29, Kan $^{R}$ & Our collection \\
\hline pssel-2HA & ssel with endogenous promoter and C-term. tandem HA fusion in pWSK I29, Kan ${ }^{R}$ & {$[8]$} \\
\hline pssel-2HA & sifA with endogenous promoter and internal tandem HA fusion in $\mathrm{PACYCI} 84$ & [37] \\
\hline PIVET5n & $\operatorname{tnp} R-l a c Z, s a c B, \mathrm{R} 6 \mathrm{~K}$ ori, bla, Amp $\mathrm{R}^{\mathrm{R}}$ & [29] \\
\hline $\mathrm{PP}_{\mathrm{sse}} \mathrm{A}^{-l a c Z}$ & sseA promoter fused to tnpR-lacZ in pIVET5n, $\mathrm{Amp}^{R}$ & [29] \\
\hline $\mathrm{PP}_{\text {sset }}-$ lac $Z$ & sseA promoter fused to tnpR-lacZ in pIVET5n, $\mathrm{Amp}^{\mathrm{R}}$ & This work \\
\hline $\mathrm{PP}_{\text {srfN }}-\mathrm{lac} Z$ & srfN promoter fused to tnpR-lacZ in pIVET5n, $\mathrm{Amp}^{\mathrm{R}}$ & This work \\
\hline $\mathrm{PP}_{\text {sifA }}-\mathrm{lac} Z$ & sifA promoter fused to tnpR-lacZ in pIVET5n, $A_{m p}{ }^{R}$ & This work \\
\hline $\mathrm{PP}_{\mathrm{ssaB}}-\mathrm{lac} Z$ & $s s a B$ promoter fused to tnpR-lacZ in pIVET5n, $A m p^{R}$ & This work \\
\hline $\mathrm{PP}_{\mathrm{ssaG}}-\mathrm{lac} Z$ & ssaG promoter fused to tnpR-lacZ in pIVET5n, $A \mathrm{mp}^{\mathrm{R}}$ & This work \\
\hline \multicolumn{3}{|l|}{ Strains } \\
\hline SLI344 & wild type $S$. enterica sv. Typhimurium, $\mathrm{Sm}^{\mathrm{R}}$ & {$[38]$} \\
\hline 14028s & wild type S. enterica sv. Typhimurium & {$[27]$} \\
\hline 14028s rpoE::cat & rpoE deletion, $\mathrm{Cm}^{\mathrm{R}}$ & [27] \\
\hline I 40282 rpoS::Tn I0dCm & rpos deletion, $\mathrm{Cm}^{\mathrm{R}}$ & {$[27]$} \\
\hline 14028s rpoN::Ap & rpoN deletion, Amp $p^{R}$ & [27] \\
\hline I4028s rpoH::PCN & $r p o H$ deletion, temperature sensitive, $A m p^{R}$ & [27] \\
\hline SLI $344 \Delta r p o E$ & Unmarked, in-frame deletion of $r p o E, \mathrm{Sm}^{\mathrm{R}}$ & This work \\
\hline SLI 344 ssrB::3FLAG & ssrB-FLAG replacement allele on chromosome & This work \\
\hline $\mathrm{SLI} 344 \mathrm{P}_{\text {sseA }}:: \mathrm{PP}_{\text {sseA }}-$-lacZ & Merodiploid containing integrated $\mathrm{P}_{\mathrm{sseA}} \mathrm{A}^{-l a c Z}$ reporter & {$[25]$} \\
\hline $\mathrm{SLI} 344 \mathrm{P}_{\text {sseL }}:: \mathrm{PP}_{\text {sseL }}-\mathrm{lacZ}$ & Merodiploid containing integrated $\mathrm{P}_{\text {sseL }}$-lac $Z$ reporter & This work \\
\hline $\mathrm{SLI} 344 \mathrm{P}_{\text {srfN }}: \mathrm{PP}_{\text {srfN }}-l a c Z$ & Merodiploid containing integrated $\mathrm{P}_{\text {srfN- }}-\mathrm{lac} Z$ reporter & This work \\
\hline $\mathrm{SLI} 344 \mathrm{P}_{\text {sifA }}: \mathrm{PP}_{\text {sifA }}-l a c Z$ & Merodiploid containing integrated $\mathrm{P}_{\text {sifA }}-\mathrm{lac} Z$ reporter & This work \\
\hline $\mathrm{SLI} 344 \mathrm{P}_{\mathrm{ssaB}}:: \mathrm{PP}_{\mathrm{ssaB}}-\mathrm{lacZ}$ & Merodiploid containing integrated $\mathrm{P}_{\mathrm{ssaB}}-\mathrm{lac} Z$ reporter & This work \\
\hline SLI344 $\mathrm{P}_{\text {ssaG }}:: \mathrm{PP}_{\text {ssaG }}-\mathrm{lac} Z$ & Merodiploid containing integrated $\mathrm{P}_{\mathrm{ssa}}-\mathrm{lac} Z$ reporter & This work \\
\hline$\Delta r p o E P_{s s e A}:: P_{s s e A}-l a c Z$ & Merodiploid containing integrated $\mathrm{P}_{\text {sse }}$-lac $Z$ reporter & This work \\
\hline$\Delta r p o E P_{\text {sseL }}:: P_{\text {sseL }}-l a c Z$ & Merodiploid containing integrated $\mathrm{P}_{\mathrm{sse}}-$-lacZ reporter & This work \\
\hline$\Delta r p o E P_{\text {srfN }:: p P_{\text {srfN }}-l a c Z}$ & Merodiploid containing integrated $\mathrm{P}_{\text {srfN }}-l a c Z$ reporter & This work \\
\hline$\Delta r p o E P_{\text {sifA }}:: P_{\text {sifA }}-l a c Z$ & Merodiploid containing integrated $\mathrm{P}_{\text {sifA }}$-lacZ reporter & This work \\
\hline$\Delta r p o E P_{\text {ssaB }}:: \mathrm{pP}_{\text {ssaB }}-l a c Z$ & Merodiploid containing integrated $\mathrm{P}_{\mathrm{ssaB}}-\mathrm{lac} Z$ reporter & This work \\
\hline 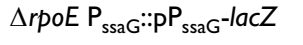 & Merodiploid containing integrated $\mathrm{P}_{\mathrm{ssaG}}-\mathrm{lacZ}$ reporter & This work \\
\hline
\end{tabular}

aSm, streptomycin; Amp, ampicillin; Cm, chloramphenicol; Kan, kanamycin 
Table 2: Primers used in this study

\begin{tabular}{ll}
\hline Primer & Sequence ${ }^{\text {ab }}$ \\
\hline BKCI83 & GCTCGAGTTTACCGCGCCGGATAACATACCG \\
BKCI84 & CACCAATTGTAGCTGAATGAAGCAACCGTTGCCAG \\
BKCI85 & CCTCGAGCGATTGCCGTCAAAGGTATTC \\
BKCI86 & CACCAATTGTTACTGATCACCGTTCTCTACGGCGCT \\
BKCI87 & GGTTTGGGGAGACATTACCTCGGATGAGCGAGCAGTTAGTGTAGGCTGGAGCTGCTTCG \\
BKCI88 & CCTAATACCTTTTCCAGTATCCCGCTATCGTCAACGCATATGAATATCCTCCTTA \\
BKCI95 & CAGCTCACTATCCAACGTTT \\
BKCI96 & TGCTTGCTCATAGTGCGGCTT \\
BKC205 & CACCAATTGTTACTATAGTAATCGGCATATTAA \\
BKC206 & CCGCTCGAGTATGGCGCTGATCGCCAC \\
SEO005 & CCGCTCGAGGTGCCATCCTTTGCCGTTT \\
SEO006 & CACCAATTGTTACATGAATCCCTCCTCAGACAT \\
SEO0II & CCGCTCGAGATATGGAGAGTGGTAGAATAG \\
SEO012 & CACCAATTGTTATAATTGTGCATATCCATAA \\
SEO095 & GCTCTAGATCAACGCCTGATAAGCGGTT \\
SEO096 & ACGCGTCGACCCACTCTTTATTGCGATCCA \\
\end{tabular}

aunderlined nucleotides indicate restriction enzyme sites; Xhol (CTCGAG), Mfel (CAATTG)

$\mathrm{b}$ bolded nucleotides indicate complementarity to $r p o E$

dependent gene expression $[21,36]$. Cultures were propagated at $37^{\circ} \mathrm{C}$ for 7 hours and samples were taken hourly to measure $\beta$-galactosidase activity using a chemiluminescence assay described previously [25]. Data was expressed as relative light units (RLU) and was normalized to the optical density $\left(\mathrm{OD}_{600 \mathrm{~nm}}\right)$ of the parent culture.

\section{Immunoblotting}

To examine the protein levels of SseB, SseL, SrfN and SifA under SPI-2 inducing conditions, we used plasmids psifA2HA, psseL-2HA and psrfN-2HA that were published previously (Table 1) [8,37]. These constructs express the given gene under the control of the endogenous promoter. Wild type and $\triangle r p o E$ cells were transformed with these plasmids and grown in LPM pH 5.8 at $37^{\circ} \mathrm{C}$ for 6 hours. Whole cell lysates were collected and analyzed by immunoblotting using anti-SseB (1:1000) [21] and antiHA (1:1000, Covance) antibodies. Blots were probed for DnaK (1:3500, Stressgen) as a control.

\section{Authors' contributions}

SEO designed and performed research, interpreted data and wrote the paper. BKC designed and interpreted research and wrote the paper. Both authors read and approved the final manuscript.

\section{Acknowledgements}

We would like to thank Jose Puente for providing $\lambda$ Red recombination plasmids, Ferric Fang for providing sigma factor mutants in the 14028s strain background, and members of the Coombes laboratory for helpful comments on this work. This work was funded by a grant to BKC from the Canadian Institute for Health Research (MOP-82704). SEO is the recipient of an Ontario Graduate Scholarship. BKC is the recipient of a New Investigator Award from the CIHR, a Young Investigator Award from the American Society of Microbiology, and an Early Researcher Award from the Ontario Ministry of Research and Innovation.

\section{References}

I. Shea JE, Hensel M, Gleeson C, Holden DW: Identification of a virulence locus encoding a second type III secretion system in Salmonella typhimurium. Proc Natl Acad Sci USA 1996, 93:2593-2597.

2. Ochman H, Soncini FC, Solomon F, Groisman EA: Identification of a pathogenicity island required for Salmonella survival in host cells. Proc Natl Acad Sci USA 1996, 93:7800-7804.

3. Cirillo DM, Valdivia RH, Monack DM, Falkow S: Macrophagedependent induction of the Salmonella pathogenicity island 2 type III secretion system and its role in intracellular survival. Mol Microbiol 1998, 30: 175-188.

4. Hensel M: Salmonella pathogenicity island 2. Mol Microbiol 2000, 36: $1015-1023$.

5. Hensel M, Shea JE, Waterman SR, Mundy R, Nikolaus T, Banks G, Vazquez-Torres A, Gleeson C, Fang FC, Holden DW: Genes encoding putative effector proteins of the type III secretion system of Salmonella pathogenicity island 2 are required for bacterial virulence and proliferation in macrophages. Mol Microbiol 1998, 30:163-174.

6. Garmendia J, Beuzon CR, Ruiz-Albert J, Holden DW: The roles of SsrA-SsrB and OmpR-EnvZ in the regulation of genes encoding the Salmonella typhimurium SPI-2 type III secretion system. Microbiology 2003, I 49:2385-2396. 
7. Worley MJ, Ching KH, Heffron F: Salmonella SsrB activates a global regulon of horizontally acquired genes. Mol Microbiol 2000, 36:749-76I.

8. Coombes BK, Lowden MJ, Bishop JL, Wickham ME, Brown NF, Duong N, Osborne S, Gal-Mor O, Finlay BB: SseL is a Salmonellaspecific translocated effector integrated into the SsrB-controlled salmonella pathogenicity island 2 type III secretion system. Infect Immun 2007, 75:574-580.

9. Osborne S, Walthers D, Tomljenovic AM, Mulder D, Silphaduang U Duong N, Lowden M, Wickham ME, Waller R, Kenney LJ, et al.: Pathogenic adaptation of intracellular bacteria by rewiring a cisregulatory input function. Proc Natl Acad Sci USA 2009 in press.

10. Browning DF, Busby SJ: The regulation of bacterial transcription initiation. Nat Rev Microbiol 2004, 2:57-65.

II. Alba BM, Gross CA: Regulation of the Escherichia coli sigmadependent envelope stress response. Mol Microbiol 2004, 52:613-619.

12. Vazquez-Torres A, Xu Y, Jones-Carson J, Holden DW, Lucia SM, Dinauer MC, Mastroeni P, Fang FC: Salmonella pathogenicity island 2-dependent evasion of the phagocyte NADPH oxidase. Science 2000, 287:1655-1658.

13. Testerman TL, Vazquez-Torres A, Xu Y, Jones-Carson J, Libby SJ, Fang FC: The alternative sigma factor sigmaE controls antioxidant defences required for Salmonella virulence and stationary-phase survival. Mol Microbiol 2002, 43:771-782.

14. Bader MW, Sanowar S, Daley ME, Schneider AR, Cho U, Xu W, Klevit RE, Le Moual H, Miller SI: Recognition of antimicrobial peptides by a bacterial sensor kinase. Cell 2005, I 22:46 I-472.

15. Crouch ML, Becker LA, Bang IS, Tanabe H, Ouellette AJ, Fang FC The alternative sigma factor sigma is required for resistance of Salmonella enterica serovar Typhimurium to anti-microbial peptides. Mol Microbiol 2005, 56:789-799.

16. Humphreys S, Stevenson A, Bacon A, Weinhardt AB, Roberts M: The alternative sigma factor, sigmaE, is critically important for the virulence of Salmonella typhimurium. Infect Immun 1999, 67:1560-1568.

17. Eriksson S, Lucchini S, Thompson A, Rhen M, Hinton JC: Unravelling the biology of macrophage infection by gene expression profiling of intracellular Salmonella enterica. Mol Microbio 2003, 47:103-118.

18. Carlsson KE, Liu J, Edqvist PJ, Francis MS: Extracytoplasmicstress-responsive pathways modulate type III secretion in Yersinia pseudotuberculosis. Infect Immun 2007, 75:3913-3924.

19. Duong N, Osborne S, Bustamante VH, Tomljenovic AM, Puente JL, Coombes BK: Thermosensing coordinates a cis-regulatory module for transcriptional activation of the intracellular virulence system in Salmonella enterica serovar Typhimurium. J Biol Chem 2007, 282:34077-34084.

20. Miticka H, Rowley G, Rezuchova B, Homerova D, Humphreys S, Farn J, Roberts $M$, Kormanec J: Transcriptional analysis of the rpoE gene encoding extracytoplasmic stress response sigma factor sigmaE in Salmonella enterica serovar Typhimurium. FEMS Microbiol Lett 2003, 226:307-3।4.

2I. Coombes BK, Brown NF, Valdez Y, Brumell JH, Finlay BB: Expression and secretion of Salmonella pathogenicity island-2 virulence genes in response to acidification exhibit differentia requirements of a functional type III secretion apparatus and Ssal. J Biol Chem 2004, 279:49804-498I5.

22. Nitta T, Nagamitsu H, Murata M, Izu H, Yamada M: Function of the sigma(E) regulon in dead-cell lysis in stationary-phase Escherichia coli. J Bacteriol 2000, I 82:523 I-5237.

23. Kabir MS, Yamashita D, Koyama S, Oshima T, Kurokawa K, Maeda M Tsunedomi R, Murata M, Wada C, Mori H, et al.: Cell lysis directed by sigmaE in early stationary phase and effect of induction of the rpoE gene on global gene expression in Escherichia coli. Microbiology 2005, I 51:2721-2735

24. Walthers D, Carroll RK, Navarre WW, Libby SJ, Fang FC, Kenney LJ: The response regulator SsrB activates expression of diverse Salmonella pathogenicity island 2 promoters and counters silencing by the nucleoid-associated protein H-NS. Mol Microbiol 2007, 65:477-493.

25. Coombes BK, Wickham ME, Lowden MJ, Brown NF, Finlay BB: Negative regulation of Salmonella pathogenicity island 2 is required for contextual control of virulence during typhoid. Proc Natl Acad Sci USA 2005, 1 02:17460-17465.
26. Rhodius VA, Suh WC, Nonaka G, West J, Gross CA: Conserved and variable functions of the sigmaE stress response in related genomes. PLoS Biol 2006, 4:e2.

27. Bang IS, Frye JG, McClelland M, Velayudhan J, Fang FC: Alternative sigma factor interactions in Salmonella : sigma and sigma promote antioxidant defences by enhancing sigma levels. Mol Microbiol 2005, 56:8 I I-823.

28. Datsenko KA, Wanner BL: One-step inactivation of chromosomal genes in Escherichia coli K-I 2 using PCR products. Proc Natl Acad Sci USA 2000, 97:6640-6645.

29. Brown NF, Vallance BA, Coombes BK, Valdez Y, Coburn BA, Finlay BB: Salmonella pathogenicity island 2 is expressed prior to penetrating the intestine. PLoS Pathog 2005, I:e32.

30. Coombes BK, Brown NF, Kujat-Choy S, Vallance BA, Finlay BB: SseA is required for translocation of Salmonella pathogenicity island-2 effectors into host cells. Microbes Infect 2003, 5:56 I-570.

31. Beuzon CR, Meresse S, Unsworth KE, Ruiz-Albert J, Garvis S, Waterman SR, Ryder TA, Boucrot E, Holden DW: Salmonella maintains the integrity of its intracellular vacuole through the action of SifA. EMBO J 2000, 19:3235-3249.

32. Brumell JH, Tang P, Zaharik ML, Finlay BB: Disruption of the Salmonella-containing vacuole leads to increased replication of Salmonella enterica serovar typhimurium in the cytosol of epithelial cells. Infect Immun 2002, 70:3264-3270.

33. Ruiz-Albert J, Mundy R, Yu XJ, Beuzon CR, Holden DW: SseA is a chaperone for the SseB and SseD translocon components of the Salmonella pathogenicity-island-2-encoded type III secretion system. Microbiology 2003, I49: I I03-I I I I.

34. Zurawski DV, Stein MA: SseA acts as the chaperone for the SseB component of the Salmonella Pathogenicity Island 2 translocon. Mol Microbiol 2003, 47:|34|-|35|.

35. Rytkonen A, Poh J, Garmendia J, Boyle C, Thompson A, Liu M, Freemont P, Hinton JC, Holden DW: SseL, a Salmonella deubiquitinase required for macrophage killing and virulence. Proc Nat Acad Sci USA 2007, 1 04:3502-3507.

36. Deiwick J, Nikolaus T, Erdogan S, Hensel M: Environmental regulation of Salmonella pathogenicity island 2 gene expression. Mol Microbiol 1999, 3 I: 1759-I773.

37. Brumell JH, Goosney DL, Finlay BB: SifA, a type III secreted effector of Salmonella typhimurium, directs Salmonella-induced filament (Sif) formation along microtubules. Traffic 2002, 3:407-4I5.

38. Wray C, Sojka WJ: Experimental Salmonella typhimurium infection in calves. Res Vet Sci 1978, 25:|39-|43.

Publish with Biomed Central and every scientist can read your work free of charge

"BioMed Central will be the most significant development for disseminating the results of biomedical research in our lifetime. "

Sir Paul Nurse, Cancer Research UK

Your research papers will be:

- available free of charge to the entire biomedical community

- peer reviewed and published immediately upon acceptance

- cited in PubMed and archived on PubMed Central

- yours - you keep the copyright 